\title{
Elk, Mule Deer, and Cattle Foraging Relationships on Foothill and Mountain Rangeland
}

\author{
Wendy L. F. Torstenson, ${ }^{1}$ Jeffrey C. Mosley, ${ }^{2}$ Tracy K. Brewer, ${ }^{3}$ \\ Michael W. Tess, ${ }^{4}$ and James E. Knight ${ }^{5}$ \\ Authors are ${ }^{1}$ Research Associate, ${ }^{2}$ Professor, ${ }^{3}$ Assistant Research Professor, ${ }^{4}$ Professor, and \\ ${ }^{5}$ Professor, Department of Animal and Range Sciences, Montana State University, Bozeman, MT 59717.
}

\begin{abstract}
Foraging niche overlap among Rocky Mountain elk (Cervus elaphus nelsoni), Rocky Mountain mule deer (Odocoileus hemionus hemionus), and cattle (Bos taurus) was studied for 2 years on 37000 ha of nonforested foothill and mountain habitat in northwestern Wyoming. Microhistological analysis was used to quantify botanical composition of ungulate diets from monthly fecal collections. Feeding habitat use was determined through monthly surveys from fixed-wing aircraft to record nonsolitary animals in nonforested habitat. Kulcyznski's similarity index was used to calculate dietary and feeding habitat overlap among the 3 ungulates, and these 2 indices were multiplied together to estimate foraging niche overlap. In all seasons, elk and cattle consumed grass-dominated diets (mean $=61 \%$ and $81 \%$, respectively), although elk diets were more diverse. Mule deer consumed more forbs and shrubs than either elk or cattle $(P<0.10)$. Foraging niche overlap was high $(45 \%)$ between mule deer and elk in spring. Cattle in summer and fall had $\geq 60 \%$ foraging niche overlap with elk in spring, indicating that, in spring, elk foraged in many of the same places (largely sagebrush grassland) and ate diets similar in botanical composition to what cattle did during summer and fall (principally Festuca idahoensis, Pseudoroegneria spicata, and Achnatherum spp.). Foraging niche overlap also was high $(41 \%-51 \%)$ between elk in winter and cattle in summer and fall. Therefore, if competitive or complementary relationships existed between elk and cattle, these interactions most likely occurred on sagebrush grasslands where cattle use in summer-fall was followed by elk use in winter-spring. We recommend that resource managers focus their forage utilization and range trend monitoring in foothill sagebrush grasslands.
\end{abstract}

\section{Resumen}

Se estudió el traslape del nicho de forrajeo entre el alce de las Montañas Rocallosas, (Cervus elaphus nelsoni), el venado mula de las Montañas Rocallosas (Odocoileus hemionus hemionus) y el ganado (Bos taurus); el estudio se condujo por dos años en 37000 ha de hábitats deforestado al pie de montaña y montañoso situados en el noroeste de Wyoming. La composición botánica de la dieta de los ungulados se determinó a partir de muestras fecales colectadas mensualmente y con el uso del análisis microhistológico. El uso de hábitat alimenticio se determinó a través de muestreos mensuales por medio de un dispositivo aéreo de alas fijas para registrar los animales no solitarios en el hábitat deforestado. El índice de similaridad de Kulcyznski se uso para calcular el traslape de la dieta y del hábitat alimenticio entre los tres ungulados, y estos dos índices se multiplicaron para estimar el traslape del nicho de forrajeo. En todas las épocas de año, el alce y el ganado consumieron dietas dominadas por zacates (media $=61 \%$ y $81 \%$, respectivamente), aunque las dietas del alce fueron más diversas. El venado mula consumió más hierbas y arbustos que el alce y el ganado $(P<0.10)$. En primavera, el traslape del nicho de forrajeo fue alto $(45 \%)$ entre el venado mula y el alce. En verano y otoño, el ganado tuvo un traslape del nicho de forrajeo $\geq 60 \%$ con el alce, indicando que en primavera, el alce forrajeó en muchos de los mismos lugares (principalmente pastizal de "Sagebrush") y comió dietas similares en composición botánica a las del ganado en verano y otoño (principalmente (principalmente Festuca idahoensis, Achnatherum spp. y Pseudoroegneria spicata). El traslape del nicho de forrajeo también fue alto $(41 \%-51 \%)$ entre el alce en invierno y el ganado en verano y otoño. Por lo tanto, si existieron relaciones competitivas o complementarias entre el alce y el ganado, estas interacciones ocurrieron más probablemente en los pastizales de "Sagebrush," donde el uso por el ganado en verano-otoño es seguido por el uso del alce en invierno-primavera. Recomendamos que los manejadores de los recursos enfoquen sus monitoreos de utilización de forraje y tendencia del pastizal en los pastizales de "Sagebrush."

Key Words: dietary overlap, food habits, foraging niche overlap, habitat use, resource partitioning, wildlife-livestock relationships

\section{INTRODUCTION}

Research was funded by grants from the USDA National Research Initiative, the USDA Initiative for Future Agriculture and Food Systems, and the Montana Agricultural Experiment Station.

Correspondence: Dr Jeff Mosley, Dept of Animal and Range Sciences, Montana State University, Bozeman, MT 59717-2820. Email: jmosley@montana.edu

Manuscript received 5 January 2005; manuscript accepted 8 November 2005.
Foothill and mountain rangeland in the northern Rocky Mountains provides important foraging habitat for many wild and domestic ungulates, including Rocky Mountain elk (Cervus elaphus nelsoni), Rocky Mountain mule deer (Odocoileus hemionus hemionus), and cattle (Bos taurus). To sustain these ungulate populations and the ecological health of their 
foothill and mountain rangeland habitats, resource managers must understand the foraging relationships among these 3 ungulate species (Vavra et al. 1999).

Dietary overlap and feeding habitat use overlap are the traditional measures used to evaluate resource partitioning among free-ranging ungulates. Conclusions based on either measure alone, however, may lead to misinterpretation of foraging relationships. For example, Vavra et al. (1989) documented high dietary overlap between elk and cattle but only moderate to low spatial overlap, indicating that although elk and cattle were eating similar plant species, elk and cattle were foraging in different plant communities. Vavra et al. (1989) also documented high spatial overlap between mule deer and cattle but found low dietary overlap, indicating that mule deer and cattle were eating different plant species within the same plant communities. More recently, competition among elk, mule deer, and cattle was strongly inferred on the basis of high habitat use overlap (Stewart et al. 2002), but later discounted when a companion study revealed low dietary overlap (Stewart et al. 2003). These examples illustrate that foraging niche overlap (i.e., $\%$ dietary overlap $\times \%$ feeding habitat use overlap) provides a more meaningful metric for assessing resource partitioning (Putman 1996). It is also important to remember that although resource use overlap is often mistakenly interpreted as a measure of competition, resource use overlap can be an equally important measure of complementary relations (Berg and Hudson 1982; Keddy 1989). Even when ungulates consume identical diets from within the same plant communities at the same time, the nature of the interactions remains unknown and can be competitive, complementary, or neutral (Keddy 1989; Putman 1996).

Mule deer and elk inhabiting foothill and mountain rangeland in the northern Rocky Mountains generally have low foraging niche overlap (Vavra et al. 1989; Sheehy and Vavra 1996). Feeding habitat overlap and dietary overlap also are typically low between mule deer and cattle in these habitats (Berg and Hudson 1982; McLean and Willms 1982; Kasworm et al. 1984); however, foraging niche overlap can be significant in spring, when graminoids are succulent (Mackie 1981; Miller and Vavra 1982).

Elk and cattle are often sympatric in time and space on foothill and mountain rangeland. When this occurs, elk-cattle dietary overlap is generally high in fall, winter, and spring but not summer (Stevens 1966). Low elk-cattle dietary overlap in summer helps partition forage resources because elk-cattle feeding habitat overlap in summer is often moderate to high on foothill and mountain rangeland (Ward et al. 1973; Stewart et al. 2002, 2003).

Significant dietary and feeding habitat use overlap often occurs on foothill and mountain rangeland between summerfall cattle grazing and elk or mule deer grazing in the winterspring (Kasworm et al. 1984; Vavra et al. 1989; Crane 2002). This overlap can be beneficial to wild ungulates, for example, when elk or mule deer preferentially select feeding sites where previous cattle grazing has improved forage palatability (Willms et al. 1979; Grover and Thompson 1986; Jourdonnais and Bedunah 1990; Frisina 1992; Yeo et al. 1993; Crane 2002). However, elk and mule deer will avoid or not select sites previously grazed by cattle if cattle utilization is excessive and extant (Hudson et al. 1976; Crane 2002). Similarly, elk or mule deer grazing in late spring can compete with cattle in the subsequent summer-fall if elk or mule deer remove too much forage (Hobbs et al. 1996a, 1996b; Brewer 2002). Finally, high foraging niche overlap can contribute to unsustainable levels of forage utilization.

Whether foraging relationships between 2 or more ungulate species are benign, competitive, or complementary depends on site-specific conditions, including when grazing occurs, how much forage remains after grazing, plant community health and structure, and the ungulates' feeding strategies (Mosley 1994; Kingery et al. 1996). The sustainability of ungulate populations and their foothill and mountain rangeland habitats depends, in part, on management actions that limit competitive interactions and encourage complementary relationships whenever possible. To accomplish these goals, resource managers must first identify when (e.g., in which seasons of the year) and where (e.g., in which vegetation types) significant foraging niche overlap is likely. The objective of this study was to identify when and where foraging niche overlap was significant among nonsolitary elk, mule deer, and cattle on nonforested foothill and mountain rangeland in northwestern Wyoming. We hypothesized that foraging niche overlap would be high 1) between summer-fall cattle use and elk use in winter-spring, and 2) among elk, mule deer, and cattle in spring.

\section{METHODS}

\section{Study Area}

Data were collected from 4 ranches in Park County, Wyoming, encompassing 37000 ha of nonforested foothill and mountain habitat. Two ranches were located along the North Fork of the Shoshone River, approximately 14 and $26 \mathrm{~km}$ west of Cody, Wyoming, and 2 ranches were located along the South Fork of the Shoshone River, approximately 8 and $47 \mathrm{~km}$ southwest of Cody, Wyoming. The study area averaged $220-320 \mathrm{~mm}$ of annual precipitation historically, with $50 \%$ occurring as rain from April through July (NOAA 1999). Elevations on the study site ranged from 1750 to $3040 \mathrm{~m}$. Sagebrush grassland dominated the foothill rangelands, whereas mountain grassland dominated the mountain rangeland habitat. In the sagebrush grassland, dominant graminoids were bluebunch wheatgrass (Pseudoroegneria spicata [Pursh] A. Love), Idaho fescue (Festuca idaboensis Elmer), and Sandberg bluegrass (Poa secunda J. Presl); common forbs were spiny phlox (Phlox hoodii Richards.), western yarrow (Achillea millefolium L. var. occidentalis DC.), and rosy pussytoes (Antennaria rosea Greene); and dominant shrub species were Wyoming big sagebrush (Artemisia tridentata Nutt. spp. wyomingensis Beetle \& Young), mountain big sagebrush (Artemisia tridentata Nutt. spp. vaseyana [Rybd.] Beetle), and rubber rabbitbrush (Ericameria nauseosa [Pallas ex Pursh] Nesom \& Baird). In the mountain grassland habitat, dominant graminoids included Idaho fescue, Columbia needlegrass (Achnatherum nelsonii [Scribn.] Barkworth), and bluejoint (Calamagrostis canadensis [Michx.] Beauv.), and common forbs were western yarrow, lupine (Lupinus spp. L.), and milkvetch (Astragalus spp. L.). Primary domestic forage sources were irrigated grass-alfalfa (Medicago sativa L.) hayfields and irrigated alfalfa hayfields. Botanical nomenclature followed USDA (2005). 
The study area was comprised of a mixture of private, state, and federal lands and was grazed by wild and domestic ungulates. Dominant grazers were Rocky Mountain elk, Rocky Mountain mule deer, and cattle. Pronghorns (Antilocapra americana), Rocky Mountain bighorn sheep (Ovis canadensis canadensis), and domestic horses (Equus caballus) were also present. Grazing by wildlife occurred year-round, whereas cattle were removed from native rangeland by December and fed harvested hay until late April or early May.

\section{Food Habits and Dietary Overlap}

Fresh feces from elk, mule deer, and cattle were collected monthly from each of the ranches from January 1999 through October 2000. Feces were collected opportunistically from throughout the study area to ensure a representative sample. Five fresh fecal samples per animal species were collected monthly from each ranch (5 samples $\times 3$ ungulate species $\times$ 4 ranches $\times 22$ months $=1320$ total samples). The 5 samples from each species/ranch/month combination were combined ( 3 ungulate species $\times 22$ months $=66$ composite samples per ranch). Composite samples were sent to the Wildlife Habitat Laboratory at Washington State University, where experienced technicians used microhistological analysis to estimate botanical composition (Sparks and Malechek 1968). Six microscope slides were prepared from each composite sample, with 25 fields of view examined from each slide at $\times 100$ magnification. Although microhistological analysis of fecal samples often underestimates forbs and overestimates graminoids in growing-season diets, this bias is much less in dormant-season diets (Holechek et al. 1982). In our study, fecal sampling occurred year-round, and the growing season was confined largely to 2 months (May and June).

Food habits data were averaged each year by season: March, April, and May (spring diets); June, July, and August (summer diets); September, October, and November (fall diets); and December, January, and February (winter diets). Dietary overlap among elk, mule deer, and cattle was determined per season and year using Kulcyznski's similarity index (Oosting 1956).

\section{Feeding Habitat Use and Overlap}

Monthly survey flights over the ranches began November 1998 and ended October 2000. Each month, the 2 ranches along the North Fork of the Shoshone River were flown one day and the 2 ranches along the South Fork of the Shoshone River the next day. Monthly aerial observations provided a complete reconnaissance of open, nonforested habitats on all 4 ranches. Aerial observations began immediately after sunrise and averaged $3 \mathrm{~h}$ per flight, a peak foraging period for elk, mule deer, and cattle (Arnold and Dudzinski 1978; Geist 1981; Skovlin 1982). Aerial transects were $0.8 \mathrm{~km}$ wide at a ground speed of $140 \mathrm{~km} \cdot \mathrm{h}^{-1}$ and an altitude of $150 \mathrm{~m}$ above the ground. An Arctic Tern fixed-wing aircraft was used for all flights and flown by the same pilot for the duration of the study.

Feeding habitat (i.e., sagebrush grassland, mountain grassland, hayfield, or cattle feeding grounds) was recorded for each aerial observation of elk, mule deer, or cattle in nonforested areas on the basis of the center point of each group of animals. Only observations of $\geq 2$ adults per species were included in the data analysis because of the higher variability in feeding habitat selection exhibited by solitary animals (Sheehy and Vavra 1996). This criterion eliminated less than $10 \%$ of the aerial observations of elk, mule deer, or cattle. A sightability index was not applied to our animal counts, as we were recording feeding habitats of observed animals, not estimating total population sizes.

Percent feeding habitat use by each species was calculated per month by dividing the total number of observations into the number of observations recorded from each type of feeding habitat. Seasonal means were calculated per year. Feeding habitat use overlap was estimated using Kulcyznski's similarity index (Oosting 1956).

\section{Foraging Niche Overlap}

Foraging niche overlap between species was estimated by multiplying percent dietary overlap and percent feeding habitat use overlap (Putman 1996). Seasonal means were calculated per year.

\section{Data Analyses}

Experimental design was a split plot in time with 3 species of ungulates (elk, mule deer, and cattle) and 2 years (1998-1999 and 1999-2000). Ungulate species was the whole-plot factor and year was the subplot factor. Ranches were the replicates $(n=4)$. Using the GLM procedure of SAS (SAS 2004), analysis of variance and Duncan's Multiple Range Test (Steel et al. 1997) were used to compare the food habits and feeding habitat use patterns among ungulate species within each season. Significant differences were declared at $P \leq 0.10$.

Values of dietary overlap, feeding habitat overlap, and foraging niche overlap were compared qualitatively among the 3 ungulate species. Dietary overlap or feeding habitat overlap values $>50 \%$ indicated substantial overlap (Kingery et al. 1996). For foraging niche overlap, values of $>40 \%$ indicated exceptionally high overlap, reflecting the fact that a $40 \%$ value requires the dietary overlap and feeding habitat overlap values to be near $60 \%$ (e.g., $60 \%$ dietary overlap $\times$ $60 \%$ feeding habitat overlap $=36 \%$ foraging niche overlap).

\section{RESULTS}

\section{Food Habits and Dietary Overlap}

Elk and cattle consumed grass-dominated diets in all seasons, although elk diets included more forbs than cattle diets in summer and fall $(34 \%-36 \%$ vs. $8 \%$; Table 1$)$. Cattle diets averaged $90 \%$ graminoids in summer-fall and $72 \%$ in winterspring. Alfalfa hay fed to cattle in winter-spring accounted for the fewer graminoids in cattle diets during those seasons. Mule deer diets were more diverse than either elk or cattle diets in all seasons. In winter-spring, mule deer diets averaged $31 \%$ graminoids, 33\% browse (predominantly Artemisia spp.), $18 \%$ alfalfa, and $18 \%$ forbs other than alfalfa. In summer-fall, mule deer diets averaged $16 \%$ graminoids, $27 \%$ browse, $24 \%$ alfalfa, and $32 \%$ forbs other than alfalfa. The high percentage of alfalfa in summer-fall mule deer diets is noteworthy. Although markedly fewer mule deer were observed on the study area during these seasons, the mule deer that did remain were usually observed near hayfields. 
Table 1. Botanical composition ( \pm standard error) of cattle, elk, and mule deer diets by season on foothill and mountain rangeland in northwestern Wyoming.

\begin{tabular}{|c|c|c|c|c|c|c|c|c|c|c|c|c|}
\hline & \multicolumn{12}{|c|}{ Season } \\
\hline & \multicolumn{3}{|c|}{ Summer } & \multicolumn{3}{|c|}{ Fall } & \multicolumn{3}{|c|}{ Winter } & \multicolumn{3}{|c|}{ Spring } \\
\hline & Cattle & Elk & Mule deer & Cattle & Elk & Mule deer & Cattle & Elk & Mule deer & Cattle & Elk & Mule deer \\
\hline & ------- & $\cdots$ & "--о" & - & - n n & -------- $(9$ & 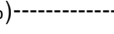 & -------- n n n & 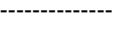 & - & $\cdots$ & --- \\
\hline \multicolumn{13}{|l|}{ Graminoids } \\
\hline Achnatherum hymenoides & 1 & & & & & & $\mathrm{~T}^{1}$ & & & 1 & & \\
\hline Achnatherum spp. & 13 & 5 & 1 & 11 & 8 & 2 & 13 & 17 & & 13 & 19 & 7 \\
\hline Agrostis spp. & 3 & 2 & $T$ & 5 & $T$ & & 7 & 4 & 1 & 7 & 2 & 1 \\
\hline Bromus marginatus & 1 & & & 2 & & & & & & & & \\
\hline Bromus spp. & & 1 & & & $T$ & & & & & & & \\
\hline Calamagrostis canadensis & & & & & & 1 & & & & & & \\
\hline Calamagrostis spp. & 7 & 6 & & 10 & 10 & 2 & 6 & 6 & 5 & 4 & 5 & 4 \\
\hline Carex aquatilis & 2 & 2 & 1 & 1 & & $\mathrm{~T}$ & & & & & & \\
\hline Carex geyeri & 1 & & & & & & & & & & & \\
\hline Carex praegracilis & 1 & 1 & & 1 & & & & & & T & T & \\
\hline Carex rostrata & 2 & $\mathrm{~T}$ & 1 & 2 & & & & & & 1 & T & \\
\hline Carex spp. & 9 & 3 & 1 & 6 & 1 & & 3 & & & 3 & 2 & 1 \\
\hline Danthonia spp. & $\mathrm{T}$ & & & 1 & $\mathrm{~T}$ & & & & & 1 & T & 1 \\
\hline Deschampsia caespitosa & & 1 & & & & & & 3 & & & T & \\
\hline Eleocharis spp. & 1 & & & 1 & & & & & & & & \\
\hline Elymus spp. & 1 & & & & & & 1 & & & & & \\
\hline Festuca idahoensis & 8 & 4 & 1 & 11 & 4 & T & 5 & 1 & & 5 & 9 & 3 \\
\hline Hordeum spp. & T & 1 & & 1 & & & 1 & & T & 1 & 1 & T \\
\hline Juncus spp. & 1 & & & 2 & & & 1 & & & 1 & & \\
\hline Koeleria macrantha & 1 & 1 & & & 1 & & & & & $\mathrm{~T}$ & & \\
\hline Phleum spp. & & & & & & $\mathrm{T}$ & & & 1 & & & \\
\hline Poa alpina & T & 1 & & & & & 1 & & & & & \\
\hline Poa spp. & 5 & 2 & 1 & 4 & 2 & T & 8 & 3 & 2 & 6 & 5 & 2 \\
\hline Pseudoroegneria spicata & 8 & 4 & 1 & 6 & 6 & 2 & 11 & 8 & 3 & 9 & 9 & 3 \\
\hline Puccinellia nuttalliana & 3 & & & 5 & 1 & & 1 & 10 & & 4 & 4 & 2 \\
\hline Scirpus spp. & 2 & & & 2 & & & T & & & & & \\
\hline Other graminoids & 21 & 20 & 7 & 19 & 20 & 11 & 16 & 14 & 10 & 15 & 16 & 12 \\
\hline Total graminoids & $91(1.8) \mathrm{a}^{2}$ & $54(4.6) \mathrm{b}$ & $14(5.2) \mathrm{c}$ & $90(1.7) \mathrm{a}$ & $53(2.1) b$ & $18(3.5) c$ & $74(2.8) \mathrm{a}$ & $66(12.8) \mathrm{a}$ & $26(4.4) b$ & $71(4.6) \mathrm{a}$ & $72(3.8) \mathrm{a}$ & $36(5.6) b$ \\
\hline \multicolumn{13}{|l|}{ Forbs } \\
\hline Astragalus spp. & $\mathrm{T}$ & 2 & 6 & & 4 & 8 & 4 & 7 & 4 & 9 & 2 & 5 \\
\hline Equisetum spp. & & & & & & & & & 1 & & & \\
\hline Erigeron spp. & & & $\mathrm{T}$ & & & & & & $\mathrm{T}$ & & & 1 \\
\hline Lupinus spp. & & 3 & 2 & & 1 & 2 & & & & & & T \\
\hline Medicago sativa & 1 & 10 & 28 & 2 & 12 & 21 & 12 & 8 & 18 & 10 & 3 & 18 \\
\hline Melilotus spp. & & & & & & 1 & & & & & & \\
\hline Oxytropis sericea & & & & & & 1 & & & & & & \\
\hline Penstemon spp. & & T & 1 & & 5 & 4 & T & 3 & 7 & 1 & 1 & 2 \\
\hline Phlox spp. & & & $\mathrm{T}$ & & & 1 & & & & & & \\
\hline Sphaeralcea spp. & & & & & T & & & & & & & \\
\hline Other forbs & 7 & 19 & 20 & 6 & 14 & 19 & 8 & 4 & 7 & 6 & 7 & 9 \\
\hline Total forbs & $8(1.6) a$ & $34(4.2) b$ & $57(4.9) c$ & $8(1.3) a$ & $36(2.6) b$ & 57 (3.2)c & 24 (2.6)a & $22(4.6) a$ & $37(3.9) b$ & $26(3.9) \mathrm{a}$ & $13(2.7) b$ & $35(5.1) \mathrm{c}$ \\
\hline \multicolumn{13}{|l|}{ Browse } \\
\hline Artemisia spp. & & 1 & 4 & $1(0.1)$ & 3 & 14 & 1 & 11 & 28 & 1 & 10 & 21 \\
\hline Cornus spp. & & 2 & 1 & & & $\mathrm{~T}$ & & & 1 & & T & 1 \\
\hline Mahonia repens & & & & & 1 & & & & & & T & \\
\hline Salix spp. & & 1 & 2 & & 2 & 2 & & & 3 & & 1 & 1 \\
\hline Shepherdia canadensis & & 4 & 6 & & 1 & 2 & & & $\mathrm{~T}$ & & & 2 \\
\hline Vaccinium spp. & & & 9 & & & $T$ & & & 1 & & & $\mathrm{~T}$ \\
\hline Conifer needles & & & 2 & T & T & 1 & & T & 2 & T & 1 & 1 \\
\hline Other browse & 1 & 4 & 5 & 1 & 4 & 6 & 1 & 1 & 2 & 2 & 2 & 3 \\
\hline Total browse & $1(0.2) \mathrm{a}$ & $12(1.8) \mathrm{b}$ & $29(3.1) \mathrm{c}$ & $2(0.6) \mathrm{a}$ & $11(1.4) \mathrm{a}$ & $25(5.6) b$ & $2(0.6) a$ & $12(9.4) \mathrm{a}$ & $37(6.0) \mathrm{b}$ & $3(1.0) a$ & $14(2.5) \mathrm{a}$ & $29(5.5) b$ \\
\hline Moss/lichen & $T$ & $\mathrm{~T}$ & $\mathrm{~T}$ & $\mathrm{~T}$ & & & $T$ & $\mathrm{~T}$ & & $T$ & 1 & \\
\hline Total & 100 & 100 & 100 & 100 & 100 & 100 & 100 & 100 & 100 & 100 & 100 & 100 \\
\hline
\end{tabular}

${ }^{1} \mathrm{~T}=$ Trace amounts, less than $1 \%$.

${ }^{2}$ Values in the same row within seasons with the same letter were not different $(P>0.10)$. 
Table 2. Dietary overlap among cattle, elk, and mule deer by season on foothill and mountain rangeland in northwestern Wyoming.

\begin{tabular}{|c|c|c|c|c|c|c|c|c|c|c|c|c|}
\hline \multirow[b]{3}{*}{ Species/season } & \multicolumn{12}{|c|}{ Species } \\
\hline & \multicolumn{4}{|c|}{ Cattle } & \multicolumn{4}{|c|}{ Elk } & \multicolumn{4}{|c|}{ Mule deer } \\
\hline & Summer & Fall & Winter & Spring & Summer & Fall & Winter & Spring & Summer & Fall & Winter & Spring \\
\hline & & & & & & & t & & & & & \\
\hline Cattle/summer & & 82 & 70 & 68 & 58 & 57 & 55 & 70 & 24 & 27 & 26 & 45 \\
\hline Cattle/fall & & & 66 & 68 & 55 & 61 & 53 & 71 & 24 & 27 & 28 & 46 \\
\hline Cattle/winter & & & & 80 & 64 & 67 & 65 & 70 & 39 & 43 & 43 & 60 \\
\hline Cattle/spring & & & & & 57 & 62 & 64 & 70 & 39 & 44 & 42 & 60 \\
\hline Elk/summer & & & & & & 72 & 50 & 57 & 55 & 58 & 43 & 59 \\
\hline Elk/fall & & & & & & & 60 & 63 & 50 & 60 & 54 & 63 \\
\hline Elk/winter & & & & & & & & 70 & 33 & 49 & 48 & 60 \\
\hline Elk/spring & & & & & & & & & 34 & 43 & 44 & 63 \\
\hline Mule deer/summer & & & & & & & & & & 71 & 50 & 55 \\
\hline Mule deer/fall & & & & & & & & & & & 65 & 67 \\
\hline Mule deer/winter & & & & & & & & & & & & 70 \\
\hline
\end{tabular}

Dietary overlap between elk and cattle was $>50 \%$ in all seasonal combinations (Table 2), and elk diets in spring were very similar to cattle diets in all seasons (mean $=70 \%$ dietary overlap). Mule deer diets in spring also overlapped notably with spring diets of cattle (60\% dietary overlap) and with elk diets in all seasons (mean $=61 \%$ overlap). Elk-mule deer dietary overlap was $>50 \%$ in 9 of 16 seasonal combinations (Table 2).

\section{Feeding Habitat Use and Overlap}

Seasonal feeding habitat selection by cattle was restricted, in part, by cattle grazing management practices that were typical of many ranches in the northern Rocky Mountains. During winter and spring, cattle were confined primarily to feeding grounds and fed hay, with some time spent grazing within foothill sagebrush grasslands (Table 3). During summer, cattle progressed from sagebrush grasslands into higher-elevation mountain grasslands before the pattern was reversed in fall and cattle again returned to foothill sagebrush grasslands and feeding grounds.

Although elk movements were not constrained by fencing and herding as were cattle, elk exhibited similar seasonal adjustments in feeding habitat use (Table 3). In winter and spring, elk foraged predominantly within foothill sagebrush grasslands $(54 \%$ and $72 \%$ of observations in winter and spring, respectively), whereas elk foraged predominantly in mountain grassland during summer and fall $(67 \%$ and $87 \%$ of observations in summer and fall, respectively).

Mule deer feeding habitat was predominantly within foothill sagebrush grassland during all seasons, especially in winter and spring $(92 \%$ and $98 \%$ of observations in winter and spring, respectively; Table 3). About $29 \%$ of mule deer feeding habitat use in fall occurred on hayfields.

Feeding habitat overlap (Table 4) between elk and cattle during summer-fall was high (mean $=50 \%$ overlap), but overlap was even greater between where cattle foraged in summer-fall and where elk foraged in winter-spring (mean $=$ $86 \%$ overlap). Cattle feeding habitat in summer-fall also overlapped greatly with mule deer feeding habitat in all seasons (mean $=65 \%$ overlap). Elk and mule deer feeding habitat during summer-fall did not overlap greatly $($ mean $=43 \%$ overlap). However, overlap was very high between where elk foraged in winter-spring and where mule deer foraged in all seasons (mean $=68 \%$ overlap), principally in the foothill sagebrush grasslands.

\section{Foraging Niche Overlap}

Elk, mule deer, and cattle may eat similar diets, as expressed by dietary overlap, or occupy similar vegetation types when foraging, as expressed by feeding habitat overlap. However, the potential for competitive or complementary interactions between elk, mule deer, and cattle is greatest when these

Table 3. Feeding habitat use ( \pm standard error) by cattle, elk, and mule deer on foothill and mountain rangeland in northwestern Wyoming.

\begin{tabular}{|c|c|c|c|c|c|c|c|c|c|c|c|c|}
\hline \multirow[b]{3}{*}{ Vegetation type } & \multicolumn{12}{|c|}{ Season } \\
\hline & \multicolumn{3}{|c|}{ Summer } & \multicolumn{3}{|c|}{ Fall } & \multicolumn{3}{|c|}{ Winter } & \multicolumn{3}{|c|}{ Spring } \\
\hline & Cattle & Elk & Mule deer & Cattle & Elk & Mule deer & Cattle & Elk & Mule deer & Cattle & Elk & Mule deer \\
\hline Hayfield & $1(12) a^{1}$ & $13(5.2) a$ & $0 \mathrm{a}$ & $5(2.7)$ a & $3(19) a$ & $29(8.5) a$ & $0 \mathrm{a}$ & $0 \mathrm{a}$ & $<1 a$ & $0 \mathrm{a}$ & $<1 a$ & $1(0.7) a$ \\
\hline Mountain grassland & $40(10.1) a$ & $67(12.0) \mathrm{a}$ & $25(16.7) \mathrm{a}$ & $24(9.8) \mathrm{a}$ & $87(3.0) b$ & $24(20.1) a$ & $0 \mathrm{a}$ & $46(12.0) b$ & $8(4.1) \mathrm{a}$ & $0 \mathrm{a}$ & $28(8.3) b$ & $1(0.5) \mathrm{a}$ \\
\hline Sagebrush grassland & 59 (10.1)a & $20(12.1 \mathrm{a}$ & 75 (16.7)a & $67(12.0) a$ & $10(4.5) b$ & 47 (20.8)ab & $11(4.2) \mathrm{a}$ & $54(12.0) b$ & $92(4.2) \mathrm{c}$ & $22(1.2) a$ & $72(8.4) b$ & $98(1.2) c$ \\
\hline Cattle feeding grounds & $0 \mathrm{a}$ & $0 \mathrm{a}$ & $0 \mathrm{a}$ & $4(2.7) \mathrm{a}$ & $0 \mathrm{a}$ & $0 \mathrm{a}$ & $89(4.2) \mathrm{a}$ & $0 \mathrm{~b}$ & $0 \mathrm{~b}$ & $78(1.2) a$ & $0 \mathrm{~b}$ & $0 \mathrm{~b}$ \\
\hline
\end{tabular}

${ }^{1}$ Values in the same row within seasons with the same letter were not different $(P>0.10)$. 
Table 4. Feeding habitat overlap among cattle, elk, and mule deer on foothill and mountain rangeland in northwestern Wyoming.

\begin{tabular}{|c|c|c|c|c|c|c|c|c|c|c|c|c|}
\hline \multirow[b]{3}{*}{ Species/season } & \multicolumn{12}{|c|}{ Species } \\
\hline & \multicolumn{4}{|c|}{ Cattle } & \multicolumn{4}{|c|}{ Elk } & \multicolumn{4}{|c|}{ Mule deer } \\
\hline & Summer & Fall & Winter & Spring & Summer & Fall & Winter & Spring & Summer & Fall & Winter & Spring \\
\hline & & & & & & & $1--$ & & & & & $\ldots$ \\
\hline Cattle/summer & & 84 & 11 & 22 & 62 & 51 & 94 & 87 & 73 & 58 & 67 & 60 \\
\hline Cattle/fall & & & 15 & 26 & 50 & 36 & 78 & 84 & 64 & 54 & 74 & 68 \\
\hline Cattle/winter & & & & 89 & 9 & 2 & 11 & 11 & 11 & 11 & 11 & 11 \\
\hline Cattle/spring & & & & & 20 & 10 & 22 & 22 & 22 & 20 & 22 & 22 \\
\hline Elk/summer & & & & & & 80 & 67 & 49 & 45 & 56 & 29 & 22 \\
\hline Elk/fall & & & & & & & 56 & 38 & 35 & 37 & 18 & 11 \\
\hline Elk/winter & & & & & & & & 82 & 73 & 57 & 62 & 55 \\
\hline Elk/spring & & & & & & & & & 80 & 64 & 80 & 73 \\
\hline Mule deer/summer & & & & & & & & & & 71 & 69 & 74 \\
\hline Mule deer/fall & & & & & & & & & & & 48 & 48 \\
\hline Mule deer/winter & & & & & & & & & & & & 93 \\
\hline
\end{tabular}

ungulates consume similar diets while foraging within similar vegetation types, as expressed by high foraging niche overlap.

Foraging niche overlap (Table 5) was very high between summer-fall cattle use and elk use in winter (46\% overlap) and spring $(60 \%$ overlap). Foraging niche overlap between cattle and elk did not exceed $40 \%$ overlap in any other seasonal combinations (Table 5). Foraging niche overlap between cattle and mule deer was low $(<40 \%$ overlap) in all seasonal combinations. Between elk and mule deer, foraging niche overlap also was generally low; however, elk and mule deer had a relatively high foraging niche overlap (45\%) during spring.

\section{DISCUSSION}

The grass-dominated diets of cattle and elk reported in this study (Table 1) agree with results from previous studies on foothill and mountain rangeland in the northern Rocky Mountains (Stevens 1966; Miller and Krueger 1976; McLean and Willms 1977; Skovlin and Vavra 1979; Berg and Hudson 1982; Kasworm et al. 1984; Vavra et al. 1989; Ngugi et al. $1992)$. For elk, graminoids were an especially important dietary component in winter and spring $(66 \%$ and $72 \%$, respectively; Table 1). These values compare favorably with elk diets on foothill rangeland in northeastern Oregon $160 \%$ graminoids in winter-spring; Skovlin and Vavra 1979), southwestern Alberta (95\% graminoids in winter-spring; Berg and Hudson 1982), north-central Montana (84\% graminoids in winter and $65 \%$ graminoids in spring; Kasworm et al. 1984), west-central Montana (77\% graminoids in spring; Stevens 1966), and south-central Wyoming (84\% graminoids in spring; Ngugi et al. 1992).

Elk and cattle in our study had high feeding habitat overlap during summer (62\%; Table 4$)$. This is common during summer in foothill and mountain rangeland in the northern Rocky Mountains (Long and Irwin 1982; Coe et al. 2001; Stewart et al. 2002), but elk sometimes favor upper and midslopes, while cattle favor lower portions of slopes (Julander and Jeffery

Table 5. Foraging niche overlap among cattle, elk, and mule deer on foothill and mountain rangeland in northwestern Wyoming.

\begin{tabular}{|c|c|c|c|c|c|c|c|c|c|c|c|c|}
\hline \multirow[b]{3}{*}{ Species/season } & \multicolumn{12}{|c|}{ Species } \\
\hline & \multicolumn{4}{|c|}{ Cattle } & \multicolumn{4}{|c|}{ Elk } & \multicolumn{4}{|c|}{ Mule deer } \\
\hline & Summer & Fall & Winter & Spring & Summer & Fall & Winter & Spring & Summer & Fall & Winter & Spring \\
\hline & & & & & & & - & & & & & \\
\hline Cattle/summer & & 69 & 7 & 15 & 36 & 29 & 51 & 61 & 19 & 16 & 17 & 27 \\
\hline Cattle/fall & & & 9 & 18 & 27 & 22 & 41 & 60 & 15 & 14 & 21 & 31 \\
\hline Cattle/winter & & & & 71 & 5 & 1 & 6 & 7 & 4 & 5 & 4 & 6 \\
\hline Cattle/spring & & & & & 12 & 6 & 14 & 15 & 9 & 9 & 9 & 13 \\
\hline Elk/summer & & & & & & 58 & 33 & 28 & 26 & 32 & 12 & 13 \\
\hline Elk/fall & & & & & & & 34 & 25 & 19 & 21 & 10 & 8 \\
\hline Elk/winter & & & & & & & & 58 & 28 & 29 & 29 & 33 \\
\hline Elk/spring & & & & & & & & & 28 & 27 & 35 & 45 \\
\hline Mule deer/summer & & & & & & & & & & 50 & 33 & 40 \\
\hline Mule deer/fall & & & & & & & & & & & 29 & 33 \\
\hline Mule deer/winter & & & & & & & & & & & & 65 \\
\hline
\end{tabular}


1964). Selection of higher slopes by elk also may limit feeding habitat overlap between cattle use in summer and elk in winter (Hart et al. 1991). We found high feeding habitat overlap between summer-fall cattle use and elk in winter-spring (mean $=75 \%$ overlap), but the potential effects of slope were not accounted for in our data. However, slope use by cattle and elk was documented on our study area in 2 companion studies (Crane 2002; Brewer 2004). These 2 studies found that both cattle in summer-fall and elk in fall-winterspring grazed primarily on slopes less than $25 \%$, indicating that cattle and elk did not use slope position to partition forage resources.

We found the species of graminoids that elk ate in winter and spring closely mirrored the ones that cattle had eaten the previous summer-fall ( $54 \%$ dietary overlap between summerfall cattle diets and winter elk diets; $70 \%$ dietary overlap between summer-fall cattle diets and spring elk diets; Tables 1 and 2). Kasworm et al. (1984) also reported that winter elk diets and summer cattle diets were highly correlated, and Berg and Hudson (1982) reported an astounding 98\% dietary overlap between summer-fall cattle diets and winter-spring elk diets. In a companion study on 2 of the 4 ranches in our study area, Crane (2002) determined that elk in winter-spring preferentially selected feeding habitat where moderate cattle grazing had occurred during the previous summer-fall.

Mule deer diets in this study were comprised of fewer graminoids than elk or cattle diets, but during spring, mule deer diets were about one-third graminoids (Table 1). Mule deer in spring commonly select young, succulent growth from grasses such as bluebunch wheatgrass, Idaho fescue, and Sandberg bluegrass (Willms and McLean 1978; Skovlin and Vavra 1979; Smith et al. 1979). For example, mule deer spring diets were $38 \%$ graminoids, $33 \%$ graminoids, and $46 \%$ graminoids in west-central Montana (Lovaas 1958), north-central Montana (Martinka 1968), and northeastern Oregon (Skovlin and Vavra 1979), respectively. Graminoid consumption by mule deer in spring was even greater on foothill sagebrush grassland and ponderosa pine (Pinus ponderosa Dougl.) habitats in southcentral British Columbia, where mule deer diets were $70 \%$ graminoids in March-May and 92\% graminoids in April alone (Willms and McLean 1978). In such situations, dietary overlap can be high between mule deer spring diets and year-round diets of elk and cattle. In our study, elk diets in all seasons averaged $61 \%$ dietary overlap with mule deer spring diets, whereas cattle diets in spring and winter had $60 \%$ overlap with mule deer spring diets (Table 2). However, in other locales, mule deer spring diets are sometimes browse dominated and have less dietary overlap with elk and cattle. For example, Kasworm et al. (1984) reported mule deer diets in March-April to be $18 \%$ graminoids and $67 \%$ browse. Of the browse consumed, $67 \%$ was creeping juniper (Juniperus horizontalis Moench), a prostrate, coniferous shrub. Similarly, Berg and Hudson (1982) found the conifer Douglas-fir (Pseudotsuga menziesii [Mirbel] Franco) to be a dominant browse species in mule deer winterspring diets that averaged 3\% graminoids and $97 \%$ browse.

Alfalfa and alfalfa hay comprised large proportions of mule deer diets in all seasons $(18 \%-28 \%$; Table 1$)$. In fall, mule deer in our study consumed $21 \%$ alfalfa, which compares closely with the $20 \%$ documented by Martinka (1968) in the Bear Paw Mountains of north-central Montana. Mule deer were abun- dant on our study area during winter and spring, and alfalfa comprised $18 \%$ of their diets. We conclude that mule deer likely consumed significant amounts of alfalfa hay that had been disbursed to cattle.

\section{MANAGEMENT IMPLICATIONS}

During most of the year on the study area, mule deer and cattle foraged within similar vegetation types but did not eat similar diets. However, in spring after cattle were no longer fed hay and were turned out to graze, nonsolitary cattle, elk, and mule deer all concentrated their foraging activities on graminoids in nonforested foothill sagebrush grassland. Cattle grazing during summer-fall also concentrated on graminoids in foothill sagebrush grasslands and mountain grasslands where elk subsequently concentrated on graminoids during winter-spring. Therefore, if competitive or complementary relationships existed between elk and cattle, these interactions most likely occurred on sagebrush grasslands where cattle use in summerfall was followed by elk use in winter-spring. Combined with the results of previous studies, our results suggest that this foraging niche overlap between summer-fall cattle use and winter-spring elk use likely benefits elk in our study area when forage utilization by cattle does not exceed moderate levels (Crane 2002). In turn, grazing by elk and mule deer in spring is unlikely to compete with cattle use in summer-fall, provided that elk or mule deer grazing is not excessive (Hobbs et al. 1996a, 1996b; Brewer 2002). We recommend that resource managers focus their forage utilization and range trend monitoring efforts in foothill sagebrush grasslands, particularly on southerly aspects, as these are preferred sites for spring grazing by elk, mule deer, and cattle (Hudson et al. 1976; Willms et al. 1979; Nelson and Leege 1982).

\section{ACKNOWLEDGMENTS}

Authors gratefully acknowledge the Wapiti Ridge Coordinated Resource Management group in Cody, Wyoming, for their assistance. We also thank the editor, Keith Owens; the associate editor, Dave Hewitt; and 2 anonymous reviewers for their helpful comments and suggestions that improved our manuscript.

\section{LITERATURE CITED}

Arnold, G. W., And M. L. Dudzinski. 1978. Ethology of free-ranging domestic animals. New York, NY: Elsevier. 198 p.

Berg, B. P., and R. J. Hudson. 1982. Elk, mule deer and cattle: functional interactions on foothills range in southwestern Alberta. In: J. M. Peek and P. D. Dalke [EDs.]. Proceedings of the Wildlife-Livestock Relationships Symposium; 20-22 April 1981; Coeur d'Alene, ID. Moscow, ID: University of Idaho Forest, Wildlife, and Range Experiment Station. p 509-519.

BREWER, T. K. 2002. Effects of spring clipping on bluebunch wheatgrass in summer [thesis]. Bozeman, MT: Montana State University. 62 p.

BREWER, T. K. 2004. Predicting utilization of foothill and mountain rangeland by cattle in summer [dissertation]. Moscow, ID: University of Idaho. $78 \mathrm{p}$.

Coe, P. K., B. K. Johnson, J. W. Stern, S. L. Findholt, J. G. Kie, and M. J. Wisdom. 2001. Responses of elk and mule deer to cattle in summer. Journal of Range Management 54:A51-A76.

CRAnE, K. K. 2002. Influence of cattle grazing on feeding site selection by Rocky Mountain elk [dissertation]. Laramie, WY: University of Wyoming. 85 p. 
FrISINA, M. R. 1992. Elk habitat use within a rest-rotation grazing system. Rangelands 14:93-97.

GeIST, V. 1981. Behavior: adaptive strategies in mule deer. In: 0. C. Wallmo [ED.]. Mule and black-tailed deer of North America. Lincoln, NE: University of Nebraska Press. p 157-224.

Grover, K. E., AND M. J. Thompson. 1986. Factors influencing spring feeding site selection by elk in the Elkhorn Mountains, Montana. Journal of Wildlife Management 50:466-470.

Hart, R. H., K. W. Hepworth, M. A. Smith, and J. W. Waggoner, JR. 1991. Cattle grazing behavior on a foothill elk winter range in southeastern Wyoming. Journal of Range Management 44:262-266.

Hobbs, N. T., D. L. Baker, G. D. Bear, and D. C. Bowden. 1996a. Ungulate grazing in sagebrush grassland: effects of resource competition on secondary production. Ecological Applications 6:200-217.

HobBs, N. T., D. L. BaKer, G. D. BeAR, AND D. C. Bowden. 1996b. Ungulate grazing in sagebrush grassland: mechanisms of resource competition. Ecological Applications 6:218-227.

Holechek, J. L., M. Vavra, and R. D. Pieper. 1982. Botanical composition determination of range herbivore diets: a review. Journal of Range Management 35:309-315.

Hudson, R. J., D. M. HeBert, AND V. C. BRink. 1976. Occupational patterns of wildlife on a major East Kootenay winter-spring range. Journal of Range Management 29:38-43.

Jourdonnais, C. S., And D. J. Bedunah. 1990. Prescribed fire and cattle grazing on an elk winter range in Montana. Wildlife Society Bulletin 18:232-240.

Julander, 0., And D. E. JefFery. 1964. Deer, elk, and cattle range relations on summer range in Utah. Transactions of the North American Wildife and Natural Resources Conference 29:404-413.

Kasworm, W. F., L. R. Irby, and H. B. Ihsle Pac. 1984. Diets of ungulates using winter ranges in northcentral Montana. Journal of Range Management 37: 67-71.

Keddy, P. A. 1989. Competition. New York, NY: Chapman and Hall. 202 p.

Kingery, J. L., J. C. Mosley, and K. C. Bordwell. 1996. Dietary overlap among cattle and cervids in northern Idaho forests. Journal of Range Management 49:8-15.

Long, A. J., AND L. L. IRWIN. 1982. Elk-cattle interactions in the Bighorn Mountains, Wyoming. In: J. M. Peek and P. D. Dalke [EDS.]. Proceedings of the WildlifeLivestock Relationships Symposium; 20-22 April 1981; Coeur d'Alene, ID. Moscow, ID: University of Idaho Forest, Wildlife, and Range Experiment Station. p 553-564.

LovaAs, A. L. 1958. Mule deer food habits and range use, Little Belt Mountains, Montana. Journal of Wildlife Management 22:275-283.

MACKIE, R. J. 1981. Interspecific relationships. In: 0. C. Wallmo [ED.]. Mule and black-tailed deer of North America. Lincoln, NE: University of Nebraska Press. p 487-508.

MaRTINKA, C. J. 1968. Habitat relationships of white-tailed and mule deer in northern Montana. Journal of Wildlife Management 32:558-565.

McLean, A., AND W. Willms. 1977. Cattle diets and distribution on spring-fall and summer ranges near Kamloops, British Columbia. Canadian Journal of Animal Science 57:81-92.

McLean, A., And W. Willms. 1982. Competition between cattle and mule deer on winter range in British Columbia. In: J. M. Peek and P. D. Dalke [eds.]. Proceedings of the Wildlife-Livestock Relationships Symposium; 20-22 April 1981; Coeur d'Alene, ID. Moscow, ID: University of Idaho Forest, Wildlife, and Range Experiment Station. p 479-484.

Miller, R. F., And W. C. Krueger. 1976. Cattle use on summer foothill rangelands in northeastern Oregon. Journal of Range Management 29:367-371.

Miller, R. F., and M. Vavra. 1982. Deer, elk and cattle diets on northeastern Oregon rangelands. In: J. M. Peek and P. D. Dalke [EDS.]. Proceedings of the Wildlife-Livestock Relationships Symposium; 20-22 April 1981; Coeur d'Alene, ID. Moscow, ID: University of Idaho Forest, Wildlife, and Range Experiment Station. p 500-508.
MosLey, J. C. 1994. Prescribed sheep grazing to enhance wildlife habitat on North American rangelands. Sheep Research Journal (Special Issue):79-91.

[NOAA] National Oceanic and Atmospheric Administration. 1999. Wyoming climatological data. Asheville, NC: US Department of Commerce National Climate Center.

Nelson, J. R., And T. A. LeEge. 1982. Nutritional requirements and food habits. In: J. W. Thomas and D. E. Toweill [EDS.]. Elk of North America: Ecology and management. Harrisburg, PA: Stackpole Books. p 323-367.

Ngugi, K. R., J. Powell, F. C. Hinds, and R. A. OLson. 1992. Range animal diet composition in southcentral Wyoming. Journal of Range Management 45:542-545.

Oosting, H. J. 1956. The study of plant communities. San Francisco, CA: W. H. Freeman. $440 \mathrm{p}$.

Putman, R. J. 1996. Competition and resource partitioning in temperate ungulate assemblies. London: Chapman and Hall. $131 \mathrm{p}$.

[SAS] SAS InStITUTE. 2004. SAS/STAT 9.1 user's guide. Cary, NC: SAS Institute, Inc. 5136 p.

Sheehy, D. P., And M. VavRa. 1996. Ungulate foraging areas on seasonal rangeland in northeastern Oregon. Journal of Range Management 49:16-21.

SKovLIN, J. M. 1982. Habitat requirements and evaluations. In: J. W. Thomas and D. E. Toweill [EDS.]. Elk of North America: Ecology and management. Harrisburg, PA: Stackpole Books. p 369-413.

Skoviln, J., and M. Vavra. 1979. Winter diets of elk and deer in the Blue Mountains, Oregon. Portland, OR: US Department of Agriculture, Forest Service, Pacific Northwest Forest and Range Experiment Station. Research Paper PNW-260. $21 \mathrm{p}$.

Smith, M. A., J. C. Malechek, and K. O. Fulgham. 1979. Forage selection by mule deer on winter range grazed by sheep in spring. Journal of Range Management 32:40-45.

Sparks, D. R., And J. C. Malechek. 1968. Estimating percentage dry weight in diets using a microscopic technique. Journal of Range Management 21:264-265.

Steel, R. G. D., J. H. Torrie, and D. A. Dickey. 1997. Principles and procedures of statistics: A biometrical approach. 3rd ed. New York, NY: McGraw-Hill. $666 \mathrm{p}$.

Stevens, D. R. 1966. Range relationships of elk and livestock, Crow Creek drainage, Montana. Journal of Wildlife Management 30:349-363.

Stewart, K. M., R. T. Bowyer, J. G. Kie, N. J. Cimon, and B. K. Johnson. 2002. Temporospatial distributions of elk, mule deer, and cattle: resource partitioning and competitive displacement. Journal of Mammalogy 83:229-244.

Stewart, K. M., R. T. Bowyer, J. G. Kie, B. L. Dick, and M. Ben-David. 2003. Niche partitioning among mule deer, elk, and cattle: do stable isotopes reflect dietary niche? Ecoscience 10:297-302.

[USDA] US Department of Agriculture. 2005. The PLANTS database, version 3.5. Available at: http//plants.usda.gov. Accessed 1 November 2005.

Vavra, M., M. Mclnnis, and D. Sheehy. 1989. Implications of dietary overlap to management of free-ranging large herbivores. Proceedings of the Western Section of the American Society of Animal Science 40:489-495.

Vavra, M., M. J. Willis, And D. P. SheEhy. 1999. Livestock-big game relationships: conflicts and compatibilities. In: K. L. Launchbaugh, K. D. Sanders, and J. C. Mosley [EDS.]. Proceedings of the Grazing Behavior of Livestock and Wildlife Symposium; 23-24 March 1999; Moscow, ID. Moscow, ID: University of Idaho Forest, Wildlife, and Range Experiment Station Bulletin 70. p 130-136.

Ward, A. L., J. J. Cupal, A. L. Lea, C. A. OAkley, and R. W. Weeks. 1973. Elk behavior in relation to cattle grazing, forest recreation, and traffic. Transactions of the North American Wildlife and Natural Resources Conference 38:327-337.

Willms, W., and A. McLean. 1978. Spring forage selection by tame mule deer on big sagebrush range, British Columbia. Journal of Range Management 31: 192-199.

Willms, W., A. McLean, R. Tucker, and R. Ritcey. 1979. Interactions between mule deer and cattle on big sagebrush range in British Columbia. Journal of Range Management 32:299-304.

Yeo, J. J., J. M. Peek, W. T. Wittinger, and C. T. Kvale. 1993. Influence of restrotation cattle grazing on mule deer and elk habitat use in east-central Idaho. Journal of Range Management 46:245-250. 